\title{
Television and Political Life
}

Studies in six European countries

Edited by

Anthony Smith

for Writers' and Scholars' Educational Trust 
(C) Writers' and Scholars' Educational Trust 1979

All rights reserved. No part of this publication may be reproduced or transmitted, in any form or by any means, without permission.

First published in 1979 by

THE MACMILLAN PRESS LTD

London and Basingstoke

Associated companies in Delhi Dublin

Hong Kong Johannesburg Lagos Melbourne

New York Singapore and Tokyo

British Library Cataloguing in Publication Data

Television and political life.

1. Television in politics - Europe

I. Smith, Anthony, b. 1938

$384.55^{\prime} 4^{\prime} 094$

HE8700.7.P6

ISBN 978-0-333-24328-2 ISBN 978-1-349-16073-0 (eBook)

DOI 10.1007/978-1-349-16073-0

This book is sold subject to the standard conditions of the Net Book Agreement.

The paperback edition of this book is sold subject to the condition that it shall not, by way of trade or otherwise, be lent, resold, hired out, or otherwise circulated without the publisher's prior consent in any form of binding or cover other than that in which it is published and without a similar condition including this condition being imposed on the subsequent purchaser. 


\section{Contents}

Notes on Contributors iv

Preface vi

Introduction viii

1 Britain: The Mysteries of a Modus Vivendi 1 ANTHONY SMITH

2 France: The Monopoly that Won't Divide 41 ANTOINE DE TARLÉ

3 Italy: From Party Occupation to Party Partition 76 Fabio luca cavazza

4 Federal Republic of Germany: From Democratic Showcase to Party Domination

ALFRED GROSSER

5 Sweden: Freedom's Boundaries 142

ÅKE ORTMARK

6 Holland: The Shaky Pillars of Hilversum 191 HERMAN WIGBOLD

7 Some Conclusions

ANTHONY SMITH

Notes and References $\quad 239$

Bibliography 249

Index 257 


\section{Notes on Contributors}

FABIO LUCA CAVAZZA is Vice-Chairman of the Board and Editor of $I l$ Sole 24 Ore, the financial and economic daily paper published in Milan. He was a founder of the journal Il Mulino of Bologna, and of the publishing house of the same name, of which he is today a Director. Together with Stephen Graubard, Editor of Daedalus, he edited Il Caso Italiano (1974).

Alfred grosser is Director of the Graduate Programme of the Institut d'Études Politiques, Paris. He was Director of International Research on Media and Politics for the International Political Science Association, chairing symposia in Bucharest and Montreal. He has written extensively on post-war Germany, and was awarded the German Peace Prize in 1975 and the Theodor Heuss Prize in 1978 for his work in 'explaining the Federal Republic of Germany to France' and for having helped to promote German democracy in Germany, by pointing out and criticising undemocratic trends.

$\AA$ KE ORTMARK is by training an economist, who has worked on newspapers, magazines and as a commentator and producer in Swedish radio and television. He is Head of the Foreign Affairs section in the news department of Sweden's Channel One. His books include The Power Game of Sweden (1967), The Unknown Holders of Power (1969) and The Tools of Power (1971). 
ANTHONY SMITH is a television producer who has written extensively on problems of media policy in regard to broadcasting and the press. He was for five years Research Fellow at St Antony's College, Oxford. He provided international research material for the Committee on the Future of Broadcasting, 1977 (the Annan Committee). He is the author of The Shadow in the Cave - the Broadcaster, the Audience and the State (1974) and The Politics of Information (1978).

ANTOINE DE TARLÉ is a consultant on problems of finance and management in French broadcasting. He has written for a number of journals including the Revue Politique et Parlementaire, Esprit and Intermedia. He is a member of the Editorial Board of the monthly Etudes.

HERMAN WIGBOLD has worked in Dutch journalism since 1950 as a specialist in social and international affairs. In the 1950s he wrote for the journals International Spectator and Socialism and Democracy. In 1960 he published a book calling for the expansion of the public sector. He has worked in television since 1960 , for a time as a documentary-maker and then as Chief Editor of the current affairs programme of VARA Television, 'Behind the News'. He was for two years the producer of Holland's weekly satirical television programme and is currently the presenter of two regular television discussion programmes. In 1970 he became Chief Editor of the daily newspaper Het Vrije Volk. 


\section{Preface}

This is the first in a series of research studies into problems of freedom of expression that has been commissioned by the Writers' and Scholars' Educational Trust (WSET) in London. WSET is an independent body that was established to gather information on and conduct research into all aspects of censorship and restraints on free expression and study the forces at work in this field. Most of the results of its work are published in its associated bimonthly journal, Index on Censorship, but the present series is designed to range more widely and deeply than is possible within the confines of a magazine. Other research studies in preparation or completed include The Greek Press under the Dictatorship and after, 1967 - 77, The Spanish Media since the Death of Franco, Censorship in Brazil and The Press in Argentina 1973-8.

The present study was commissioned from Anthony Smith in early 1977 and took just over a year to prepare. It was made possible by a generous grant from the European Cultural Foundation in Amsterdam, an international non-governmental organisation that devotes most of its income to promoting the development of European cooperation and a better understanding among European nations, and by small additional grants from Granada Television and Thames Television, to all of whom I would like to express my gratitude. Thanks are also due to the Acton Society, and especially Mrs Jackie Lebe, for secretarial and other assistance. Henry Fox translated the chapter on Germany, Geoffrey French that on Sweden and Peter Langdale the chapter on France and an earlier 
Preface vii version of the Italian chapter. Gudi Lawaetz, Ejvor Martinus and Ludi Boeken translated early drafts in the opening stages of the work.

March 1978

MICHAEL SCAMMELL

Director, Writers' and Scholars'

Educational Trust 


\section{Introduction}

The purpose of these studies is to take stock of the relationship between politics and the television medium now that the latter has reached an era of consolidation and, it might be said, maturity. For ten years now a group of new media professions active in most European societies and in North America has been exercising a new and unforeseen function within the world of political discourse. Between the world of politics and that of television lies an area of marshland obscured by fog, in which territorial rights and privileges have continually to be renegotiated and institutions rebuilt. The medium of television performs many cultural and entertainment functions in addition to its brokerage between electorate and politicians (and some would say that in these other functions it has a far greater impact) but each system of broadcasting in Europe stands upon foundations dug inside the world of politics: television drama, sport, education and entertainment cannot be secure in situations where the constitutional links between society and broadcasting are unsound.

The theories of press freedom which seemed to be firmly established within Western countries at the end of the Second World War are grossly inadequate tools for dealing with the problems of the electronic media. None of the rights seems to translate from one medium to the other. The broadcaster seems at times to be a kind of journalist, at other times a kind of public functionary. Since he is the means by which others exercise their freedom to communicate with the society, can he too have the 
same freedoms? Since he is dependent for his income and his legal existence upon the legislature can he ever really exercise the freedom of comment which was thought to be the mainstay of a free press? In the age of mechanical rather than electronic media, the difference between censorship and freedom was much easier to perceive. The media are not to blame for the complication: the conduct of politics has also altered.

These problems were given solutions of a kind in the 1950s and 1960 s, but the institutions and assumptions which existed in those years have taken a severe buffeting in the 1970s, an era characterised by chastened ideals and depleted hopes. This project was born of the desire to see how, in practice, the relationship between these two entities has been shaping since the end of that heady period of growth in the 1960s when money and opportunity seemed to be for ever expanding. There have, of course, been many major obvious organisational changes; in France a completely new system has been constructed, in Italy the monopoly of the RAI has been overthrown, in all the other countries important national investigations have been held into the future development of the existing institutions. But it is not enough to describe structures and constitutions; what happens in practice is often very different from constitutional theory and political intention. The ways in which television presents politics and the ways in which politicians influence television have to be explained in terms of the political and journalistic culture of the societies concerned. It was decided, therefore, at an early stage of this project that the best method would be to choose a limited group of societies and a small team of people all of whom are concerned with television in one or more of the countries concerned, but each from a different professional angle. It was hoped that, by this means, the studies would contain sufficient parallel material for comparisons to be drawn but from a variety of different perspectives. The group contains a newspaper publisher, a television presenter, a newspaper editor, a civil servant, a political scientist, a television producer. Of the six, five are citizens of the countries about which they write; in the case of the chapter on Germany the writer, Professor Alfred Grosser, has acted as an influential interpreter of Germany in France (and of France in Germany).

The project was initiated by Michael Scammell, Editor of Index on Censorship and Director of Writers' and Scholars' Educational 


\section{$\mathrm{x}$ Introduction}

Trust (WSET), and when the project had reached its middle stage a conference was held at the Aspen Institute in Berlin, where the Director, Shepherd Stone, acted as host to a conference at which the whole of the first draft was subjected to the detailed criticism of a group of German nationals drawn from the worlds of politics, broadcasting and the press. Roger Errera, Maître des Requêtes au Conseil d'État and Maître de Conférences at the Institut d'Études Politiques de Paris, and Robert McKenzie, Professor of Sociology (with Special Reference to Politics) at the London School of Economics, have acted as advisers and critics during the course of the project. The thanks of the editor and writers are thus due to a wide circle of expert and generous supporters and advisers, including Professor Jay Blumler, who provided detailed criticism of one of the chapters.

A. S. 